\title{
ÉTICA Y ECONOMÍA (2008)
}

En el curso que imparto desde hace muchos años sobre "Ética, sociedad y empresa", acostumbro decir a los estudiantes que se trata de la materia más importante de todas las materias, de todas las carreras, de todas las universidades. Doy dos pruebas irrefutables: primero, porque la ética va dirigida al ser mejor de las personas y "nada es ni más importante ni más difícil que llegar a ser plenamente persona", decía Píndaro, hace muchos siglos. Cuando le preguntaban a Sócrates: "Maestro, ¿qué es lo más importante para cada hombre?", él señalaba el frontispicio del templo de Delfos, donde estaba escrito en letras enormes: "conócete a ti mismo", para ser tú mismo. A Julián Marías, al hablar sobre distintos oficios, le preguntaron: ¿y cuál es el oficio más importante? Pronto contestó: "el oficio de ser hombre". Martín Heidegger, hablando de las grandes responsabilidades del hombre, decía: "la máxima es la responsabilidad de ser-se".

Sería insensato aportar más testimonios sobre algo que es evidente en sí mismo. Porque, ¿qué puede haber más importante que el ser mejor de cada persona, su plenificación, su realización?

La gran mayoría de las materias universitarias se dirigen al quehacer de los individuos en la sociedad. Pero esto es parte de la patología del hombre contemporáneo: darle más importancia al quehacer que al ser del que lo hace. Por otra parte, como dice Henri Bergson: "lo que hacemos depende de lo que somos". Hombres de calidad realizan actos de calidad. 
Esta razón sería suficiente para demostrar que la ética es la materia más importante: Es la ciencia de la plenificación humana que estudia lo bueno como plenitud, lo malo como mutilación; es la ciencia de la tensión entre autonomía y deberes; es la ciencia del bien obrar como consecuencia del ser (bien) bueno.

Decir que la ética propicia la realización personal no significa que sea generadora de egoísmos, porque el desarrollo personal implica la dimensión social. Por eso el egoísta es un hombre mutilado.

Además, existe otra gran razón por la que la ética es la materia más importante: es la única verdadera solución a los más graves problemas de México y del mundo. Las criminales injusticias sociales provocan la muerte de 46 millones de personas en un año por causa del hambre, mientras los tres hombres más ricos del mundo tienen más que las 48 naciones más pobres; 38000 millones de dólares serían suficientes para resolver las más graves necesidades de alimento, salud y educación. El mundo sería otro. Sin embargo, los grupos de poder prefieren gastar más de 900000 millones en armamento. A esto yo le llamo el cretinismo del poder.

Este es el más terrible pecado en contra de la humanidad: preferir armas para la destrucción de hombres y del mundo despreciando la digni226 dad de las personas, la maravillosísima dignidad de las personas. La única solución es la ética que considera al hombre como el invitado de honor al misterio de la vida, como hijo de Dios...

Empresas como Nike llegan a pagar 70 centavos de dólar por jornadas arduas de 10 horas, cuando el dueño derrocha millones en donaciones a deportistas por solo portar su logotipo.

Con razón Iñaki Ellacuría afirmaba con vehemencia: "El sistema que pone el dinero por encima de las personas y usa a las personas para producir dinero, solo por ese hecho es intrínsecamente perverso".

Esta infame injusticia social generada por el obsesivo e insaciable afán de lucro y de consumo solo puede tener remedio en el imperio de la ética que coloca al hombre como fin, nunca como medio, que dispone toda la estructura de personas y de cosas para proteger y alentar al desarrollo humano en un mundo, nuestro mundo donde "sube el precio de las cosas, baja el precio de los hombres” (Ernesto Cardenal). 
Por eso, ahora que se han ensayado las ciencias y las técnicas más sofisticadas y los problemas sociales empeoran, es necesario interrogar a la ética en busca de luces, caminos y soluciones, si no queremos ser cómplices de tantos males.

¿Qué dirá la ética de las empresas nacionales, trasnacionales, multinacionales que emplean, casi todas, medios nocivos y hasta criminales para aumentar sus ganancias, para hacer crecer el valor de sus acciones? (Es indispensable ver la película "La corporación" para tener idea de la monstruosidad a la que llegan este tipo de compañías adoradoras del dinero y de la fama y destructoras de los consumidores.)

¿Qué dirá la ética de las pocas familias mexicanas dueñas de México, qué dirá de los multimillonarios mexicanos que aparecen en las listas de los hombres más ricos del mundo (Forbes, Fortune)?

En relación con esta abundantísima acumulación de riquezas, la ética, la conciencia moral, tiene sus sentencias bien claras: "Lo que los hombres necesitan para vivir es propiedad dada por la naturaleza". "El afán de riquezas no es racional porque tiene un objetivo de vida no buena." "El afán de riquezas (crematística) es antinatural y supone que unos toman cosas de otros" (frases de la Política de Aristóteles).

$\mathrm{Si}$, como dice el Génesis, Dios creó la tierra para todos los hijos de los hombres, para la satisfacción de sus necesidades, es evidente que lo único que legitima el régimen de propiedad privada es si y solo si, en este régimen, se administran mejor los recursos de todos a favor de todos.

¿Qué dirá la ética de los mexicanos dueños de una inmensa riqueza hecha con recursos y trabajos mexicanos que transfieren sus empresas a consorcios extranjeros por el exclusivo beneficio personal, cuando el país está tan necesitado de avanzar hacia cierta autosuficiencia o por lo menos evitar una mayor dependencia económica que repercute en la dependencia política y en pérdida de soberanía?

¿Qué dirá la ética de los políticos que han reducido su acción a seguir las estrategias para mantener o conquistar el poder y que desprecian el gran objetivo que es el bien común? ¿Qué dirá la ética de los políticos que para favorecer sus intereses y los de su partido ponen en riesgo la seguridad nacional y la paz social? 
¿Qué dirá la ética de las universidades que no estudian ética, que no dan formación ética ni son la conciencia crítica de la sociedad y saben muy bien que los más graves problemas de México y del mundo se deben a la corrupción y a las agresiones a la ética?

El juicio de la ética reprobaría a las universidades que emplean el privilegio de su situación económica y cultural solo para el provecho de los universitarios e ignoran el compromiso que tienen con esa parte sacrificada de la sociedad que hace posible la formación, la investigación y la docencia. La universidad tiene la grave obligación de denunciar y anunciar, porque en esto consiste la construcción de la utopía creadora.

¿Qué dirá la ética sobre la procuración de la justicia? Tal vez resulta el más grave de los delitos sociales en nuestra sociedad: el comportamiento, absolutamente perverso, de muchísimos responsables de custodiar la justicia: abogados, policías, jueces y hasta magistrados. Ellos son en gran parte los responsables, por su corrupción y venalidad, de esta situación que vive México de inseguridad, indefensión, temor e impotencia. Increíble que personas con formación y muchas con privilegios sociales, vendan su dignidad por unas monedas, muchas veces ensangrentadas. ¿Por qué las cárceles siempre están llenas de inocentes y de la miseria que produce una sociedad cruelmente injusta?

¿Qué dirá la ética de la economía que debe ser "el arte de hacer posible lo necesario" (Pedro Aspe), "ciencia de la administración de los recursos escasos" que debe procurar crecimiento de bienes y equidad en los beneficios?

El crecimiento económico no basta para que se dé el desarrollo económico. México ha tenido periodos de muy alto crecimiento, pero no ha propiciado el desarrollo económico porque solo ha beneficiado a los de siempre. Es indispensable un beneficio equitativo.

Es urgente interrogar a la ética sobre la defensa apasionada del mercado libre cuando la historia, magistra vitae, y la evidencia cotidiana muestran que entre poderosos y débiles la libertad se convierte en opresión de los débiles. Libertad de intercambio y de mercado, sí, pero cuando se logran igualdades básicas. Un buen ejemplo es la política seguida por la Unión Europea: primero ayuda a las naciones que quieren 
incorporarse para que logren ciertos rangos de igualdad y luego se da la incorporación.

En México, la causa principal de la desigualdad social es la "libertad" entre poderosos y débiles. La enorme mayoría de los trabajadores con salarios mínimos o inferiores los aceptan por necesidad. Por eso, lo sabemos muy bien, este sistema requiere un ejército de desempleados. Este ejército es el gran argumento para la explotación inmisericorde: si no estás de acuerdo con tu salario, allí están esos millones dispuestos a trabajar por menos.

Ya es hora de que los teóricos de la economía y, sobre todo, los dueños del gran capital con sensibilidad social inventen procedimientos para, por lo menos, disminuir el número de desempleados, de extremadamente pobres, de indigentes, de explotados. No se pide el regalo o la limosna. Se espera de gente noble y digna que encuentren caminos (que sí existen) de beneficiarse, pero beneficiando, y que supriman de una vez por todas el hábito perverso de usar a las personas como medios e instrumentos de producción de dinero. Esto se espera de todos los hombres, pero especialmente de aquellos que se dicen cristianos. 
CITAM Derechos Reservados.

La reproducción total o parcial de este artículo se podrá hacer si el ITAM otorga la autorización previamente por escrito. 